\title{
Microbial Liquid Culture
}

National Cancer Institute

\section{Source}

National Cancer Institute. Microbial Liquid Culture. NCI Thesaurus. Code C102668.

A method for growing microorganisms in liquid culture media. 